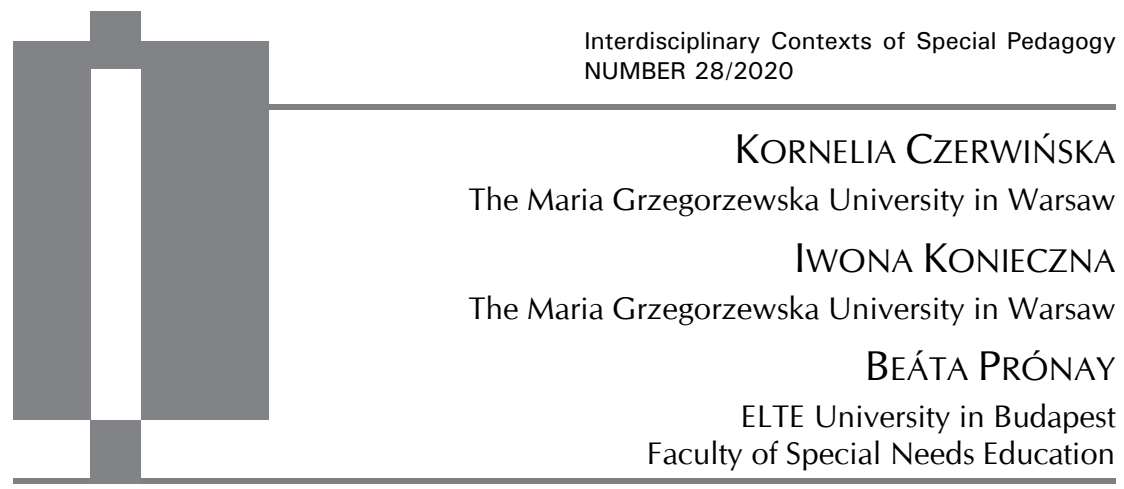

\title{
Education for students with disabilities - Polish and Hungarian solutions ${ }^{1}$
}

\begin{abstract}
Kornelia Czerwińska, Iwona Konieczna, Beáta Prónay, Education for students with disabilities - Polish and Hungarian solutions. Interdisciplinary Contexts of Special Pedagogy, no. 28, Poznań 2020. Pp. 93-127. Adam Mickiewicz University Press. ISSN 2300-391X. e-ISSN 2658-283X. DOI: https://doi.org/10.14746/ikps.2020.28.06

The article is a direct outcome of a discourse aimed at exchanging experiences and views in the area of education and rehabilitation for people with disabilities in Poland and Hungary, undertaken as part of scientific cooperation between universities which deal with the issues of special education among others. The authors attempt to perform and present a comparative analysis of current academic solutions for students with disabilities in both countries. Similarities and differences in the solutions discussed, especially problematic areas currently showing in the educational systems, constitute the basis for further discussion and research aimed at developing best practices that would ensure quality education for children and adolescents with disabilities.
\end{abstract}

KEY WORDS: education, disability, students with disabilities, integration, inclusion

1 This article is produced as part of the cooperation agreement on common objectives. Reference no.: BGGyK/3324/1 (2017)T129. 


\section{Introduction}

Effective education is considered a necessary condition for the development of modern, knowledge-based societies as well as a basic tool to improve life quality at the individual and social level. Educational policy in many countries includes activities that promote the openness of the educational system. Nowadays, it is regarded essential to develop effective solutions oriented at providing wider access to education at all levels and meeting educational and developmental needs of all students, including, in particular, children and teenagers at risk of social marginalization.

The structure and functioning of the educational system are country-specific and depend on a number of political, economic, and sociocultural factors. ${ }^{2}$ The complex nature of these factors is also manifest in solutions regarding education for students with disabilities adapted in different countries. The variety of educational models for this group of students introduced in various countries results from, among others: different history, including the political system and schooling development, different level of development and availability of modern technology, differences in access to information on rehabilitation opportunities, differences in the aims and strategies of social services providing social support, the relative nature of the concept of disability, and, consequently, different definitions of disability, etc. ${ }^{3}$ Contemporary systems of education for students with disabilities use such a wide range of organizational forms that it is difficult to produce a correct and useful typology of these forms. ${ }^{4}$

${ }^{2}$ M. Satoła, „Edukacja specjalna w państwach Unii Europejskiej”, [in:] Postawy wobec niepetnosprawności, L. Frąckiewicz (Ed.), Wydawnictwo Uczelniane Akademii Ekonomicznej im. K. Adamieckiego w Katowicach, Katowice, 2002, p. 35.

3 Z. Gajdzica, „Komparatystyka jako dział wiedzy pedagogiki specjalnej”, [in:] Edukacja $i$ wsparcie społeczne osób z niepetnosprawnością w wybranych krajach europejskich, J. Wyczesany, Z. Gajdzica (Eds.), Oficyna Wydawnicza “Impuls," Cracow, 2005, pp. 25-26.

${ }^{4}$ A. Firkowska-Mankiewicz, G. Szumski, „Pedagogika specjalna i system kształcenia osób z niepełnosprawnościami w Polsce", [in:] Pedagogika specjalna, Vol. 2, 
The multitude of ways in which special education is organized provokes comparison of theoretical assumptions behind them, their aims, determinants, and effectiveness. The comparison of educational systems for students with disabilities with reference to philosophical and theoretical assumptions underlying these systems falls within the scope of interest of comparative special education. ${ }^{5}$ Research undertaken as part of comparative special education has many functions, including among others: an idiographic function (provides an organized, comprehensive description of educational systems in various countries) and an improvement function (improves the native educational system by adopting highly regarded solutions from other countries that are at a similar level of socioeconomic development). ${ }^{6}$

The article aims to perform and present a comparative analysis of fundamental assumptions underlying the systems of education for students with disabilities in Poland and Hungary. The description of educational solutions focuses in particular on problematic and neglected areas identified in theoretical and empirical studies where changes and improvements need to be introduced to raise the quality of educational services. The choice of Poland and Hungary for comparative analysis of special education seems justified due to the countries' similar historic and cultural experiences. Both are post-communist countries that adopted democratic reforms after 1989 and adjusted their educational policies after they rejected the previous political system. ${ }^{7}$ These countries are members of the

D.D. Smith, Wydawnictwo Naukowe PWN, Wydawnictwo Akademii Pedagogiki Specjalnej, Warsaw, 2008, p. 337.

5 Š. Vašek, A. Stankowski, Zarys pedagogiki specjalnej, Wydawnictwo Uniwersytetu Śląskiego, Katowice, 2006, p. 125.

${ }^{6} \mathrm{G}$. Szumski, Integracyjne ksztatcenie niepetnosprawnych. Sens $i$ granice zmiany edukacyjnej, Wydawnictwo Naukowe PWN, Warszawa, 2006, pp. 32-33.

${ }^{7}$ Cf. K. Wasielewski, "Ewolucja systemów oświatowych i postaw młodzieży wobec edukacji w krajach Europy Środkowo-Wschodniej", Kultura i Edukacja, no. 3(117), 2017, pp. 145-163. The study by K. Wasilewski provides a critical analysis of educational changes in (post-)communist countries that consisted mainly in imi- 
European Union that follow centralized educational policy and use - just like Denmark, Germany, France, Luxembourg, Great Britain, the Czech Republic, Estonia, Lithuania, and Slovenia - a multipath model as far as educational solutions for students with disabilities are concerned. ${ }^{8}$

\section{Education for students with disabilities in Poland}

Under the contemporary approach to special education in Poland, it should constitute a high-quality educational service that ensures meeting the unique needs of students with disabilities in terms of instructional organization and methods. Students with statements of special educational needs, issued by adjudication panels in public psychological and educational counseling centers, can receive compulsory education in special schools for students with a specific disability as well as in integrated and mainstream schools. The type of setting is chosen by parents of students with disabilities. Regardless of the unique nature of each of these settings, school is obliged to follow the psychological and educational counseling center's recommendations and to adapt educational conditions to a given student's individual needs and developmental abilities resulting from, among others, his or her health and skill level. ${ }^{9}$ The student's special educational needs are identified and essential rehabilitation interventions are determined by a team composed of teachers and specialists appointed by the school prin-

tative modernization (copying institutional and legal solutions existing in AngloSaxon countries); however, it does not directly raise the issues relating to education for students with disabilities.

${ }^{8} \mathrm{D}$. Al-Khamisy, "Kształcenie uczniów ze specjalnymi potrzebami edukacyjnymi w powszechnym systemie oświatowym", [in:] Dydaktyka specjalna w przygotowaniu do ksztatcenia uczniów ze specjalnymi potrzebami edukacyjnymi, J. Głodkowska (Ed.), Wydawnictwo Akademii Pedagogiki Specjalnej, Warszawa, 2012, p. 119.

9 B. Marcinkowska, Kształcenie uczniów z niepetnosprawnościq w Polsce - przeszłość, teraźniejszość, przyszłość, Psychologia Wychowawcza, no. 7, 2015, pp. 215-216. 
cipal. These teams develop Individualized Education and Therapy Programs (IETPs), which define, among others, strategies to adapt the organization of instruction to the type and severity of the student's disability, including the scope and method of using specialist equipment and teaching aids, activities to support the student's development, integrated interventions to be provided by teachers and specialists, forms of cooperation with the student's family, etc. ${ }^{10}$ IETPs are designed based on a multispecialist assessment of a student's functioning level and recommendations included in the statement of special educational needs. The multispecialist assessment of a student's functioning level, which is made at least twice a school year, should consider not only barriers and limitations that make it difficult for the child to fulfill the role of a student on the academic and social level, but it should also determine his or her strengths, including gifts, interests, and predisposition. Students' parents and students of age can participate in carrying out multispecialist assessments as well as in developing and making periodic modifications to IETPs. A study conducted by the Educational Research Institute shows, however, that the actual participation of parents in planning their child's education and therapy is not great in school practice. The vast majority of parents in the study $(74 \%)$ did not take part in developing IETPs and $20 \%$ of these parents did not know what an IETP was. ${ }^{11}$

It is important to underline that the Regulation of the Minister of National Education of August 9, 2017, recommends that rehabilitation activities in IETPs take into particular consideration work on learning and improving communication skills in students with disorders that have a negative impact on this developmental area. In the case of blind students, training in orientation and mobility and

10 Cf. E.M. Kulesza, (Ed.), Education of students with special needs. World experience. Individualized Education and Therapy Programs (IETPS), Wydawnictwo Akademii Pedagogiki Specjalnej, Warszawa, 2013, pp. 86-159.

${ }_{11}$ P. Grzelak, P. Kubicki, M. Orłowska, Realizacja badania ścieżek edukacyjnych niepetnosprawnych dzieci, uczniów i absolwentów - raport końcowy, Instytut Badań Edukacyjnych, Warszawa, 2014, p. 104. 
in Braille is regarded essential. Learning to use the sign language or other alternative ways of communication should be provided for students with speech disorders or non-speaking students, and social skills training - for students with autism. ${ }^{12}$ The right of students with disabilities to have learning conditions adapted to their individual needs and abilities in an optimal way and to have necessary specialist classes provided should be fully respected by each type of setting regardless of the form of instruction it offers. ${ }^{13}$ However, analyses of the educational system that have been performed so far show neglect in this area, identifying the weak points of the current solutions adopted in special, integrated, and mainstream schools. ${ }^{14}$

In historical terms, special schools, which started to operate in Poland at the beginning of the 19th century, were the first form of institutional education for students with disabilities. Their segregated nature reflects the medical paradigm, according to which disability was a condition restricting a person's functioning that resulted directly from damage to his or her body and (or) dysfunctions in specific organs. Under this approach, education and rehabilitation aim at remediating developmental deficits and thus are directly determined by the type and severity of disability. Segregated

12 Regulation of the Minister of National Education of August 9, 2017 on conditions for organizing education, upbringing, and care for children and adolescents with disabilities, children and adolescents who are socially maladjusted, and children and adolescents who are at risk of social maladjustment. Journal of Laws of the Republic of Poland of August 24, 2017. Item 1578.

13 J. Głodkowska, “Uczniowie ze specjalnymi potrzebami edukacyjnymi - integracja edukacyjna procesem złożonym i trudnym”, Szkoła Specjalna, no. 1, 2013, p. 11.

${ }^{14}$ Cf. Z. Janiszewska-Nieścioruk, M. Zaorska, "Prowłączające zmiany w systemie polskiej edukacji - nowe możliwości, ograniczenia i wyzwania”, Interdyscyplinarne Konteksty Pedagogiki Specjalnej, no. 4, 2014, pp. 9-28. Z. Palak, “Tendencje w edukacji dzieci z niepełnosprawnością - szanse i zagrożenia”, Lubelski Rocznik Pedagogiczny, no. 2, Vol. XXXVI, 2017, pp. 13-31. DOI: 10.17951/lrp. 2017.36.2.13. K. Parys, "Zjawisko pozoru w systemie kształcenia uczniów niepełnosprawnych próba identyfikacji i propozycje rozwiązań", Interdyscyplinarne Konteksty Pedagogiki Specjalnej, no. 4, 2014, pp. 34-52. 
schooling was the only form of education for students with disabilities in Poland for many years and even now - despite a clear predominance of pro-inclusive trends - special education is considered an important and desirable element of the schooling system. ${ }^{15}$ Special schools usually enroll students with one type of dysfunction (e.g.: special schools for students with intellectual disabilities, with visual impairments or with hearing impairments), which allows effective use of numerous achievements in methodology of teaching that takes into consideration functional consequences of a given type of disability. The small number of students in the class (6-12 students), which depends on the type of disability (e.g. maximum 10 students in schools for children with visual impairments) facilitates the use of individualized teaching solutions. Another advantage of this type of education is the expertise of the staff, who need to have formal education that provides competence in instruction and (or) rehabilitation for students with a given type of disability. The requirement of appropriate qualifications for the staff ensures that professional support in special education is provided, both in choosing appropriate teaching strategies and in organizing rehabilitation activities. Also, it is easier to implement appropriate interventions in the area of education and rehabilitation thanks to teaching aids and specialist equipment these settings are equipped with. Moreover, research conducted among students with various disabilities in special schools indicates a relatively high level of satisfaction with such schools, relating to, among others, a feeling of acceptance and belonging. 16

Despite the above advantages of special schools, it is noted that participation in segregated education may increase the risk of students' social isolation, as these schools' self-containment in terms of

15 I. Chrzanowska, “Uczeń z niepełnosprawnością w różnych formach edukacji", [in:] W poszukiwaniu indywidualnych dróg wspierajacych wszechstronny rozwój osób z niepetnosprawnościa, B. Szczupał, A. Giryński, G. Szumski (Eds.), Wydawnictwo Akademii Pedagogiki Specjalnej, Warszawa, 2015, p. 206.

${ }^{16}$ Cf. I. Chrzanowska, Pedagogika specjalna. Od tradycji do wspótczesności, Oficyna Wydawnicza "Impuls", Cracow, 2015, pp. 540-541. 
space, curriculum, and organization as well as the homogeneity of classes reduce the number of opportunities for engagement in social interactions with nondisabled peers and in activities in mainstream public life. The lack of opportunities for the gradual development of social skills in natural situations may result in difficulty in efficient functioning in an open environment, both during school years and adulthood. Due to the number and location of special schools (in county seats), students who live further away, especially rural students, need to live in dormitories, which entails separation from their families and the loosening of social ties in their local communities. As a result of the segregated solutions' weaknesses and the emergence of other forms of special education, there has been a significant drop in the number of students attending special schools since the mid-1990s. Analyses of statistical data show that about $40 \%$ of students with disabilities attend special schools at present, which is largely related to integrated and mainstream schools' problems with adequately meeting the special educational needs of students with multiple disabilities and profound impairments. ${ }^{17}$ For example, statistical data indicate that over the last decade, there has been a growth trend in the number of students with visual impairments in non-segregated schools, but it only refers to students with milder impairments, while the majority of blind students still attend special schools. ${ }^{18}$ Moreover, the scientific study on the educational pathways of students with disabilities conducted by the Educational Research Institute proves that students who first received education in non-segregated settings are then transferred

17 I. Chrzanowska, "Stan i rozmiary udziału dzieci i młodzieży z niepełnosprawnością w edukacji włączającej w Polsce”, Forum Pedagogiczne, no. 1, 2016, p. 41. Cf. M. Zaorska, „Niepełnosprawności sprzężone w obliczu aktualnych przemian w systemowych rozwiązaniach edukacyjnych", Niepetnosprawność. Dyskursy Pedagogiki Specjalnej, no. 14, 2014, pp. 100-112.

${ }^{18}$ K. Czerwińska, “Edukacja inkluzyjna uczniów z niepełnosprawnością wzroku", [in:] Edukacja inkluzyjna. Teoria - system - metoda. Część 1, S. Sobczak, L. Pytka, T. Zacharuk (Eds.), Uniwersytet Przyrodniczo-Humanistyczny, Siedlce, 2015, pp. 98-99. 
to special schools. Forty percent of mainstream school principals and $61 \%$ of integrated school principals confirmed that students with disabilities were transferred to special schools; difficulties with the child's behavior and lack of appropriate support were pointed to as the main reason for the school transfer. ${ }^{19}$ Recently, the percentage of students with disabilities in special schools has remained at the same level, whereas the percentage of students with disabilities in mainstream and integrated classes declines at subsequent educational levels - it is the largest in preschools and the smallest in upper secondary schools. ${ }^{20}$

The departure from the medical model of disability, which focused on individual deficits, in favor of social approaches aiming at removing mental, physical, economic, and systemic barriers contributed to the development of non-segregated schooling. After 1989, a goal in the development of the educational system for students with disabilities was established in Polish educational policy to promote integrated schooling where students could receive education along with their nondisabled peers, while at the same time being provided with professional support in the area of special education. ${ }^{21}$ Integrated classes are supposed to facilitate meeting students' special educational needs and their developing social relationships thanks to a smaller number of students (15-20, including 3-5 students with a statement of special educational needs) and support of an extra teacher with a background in special education. The special educator should introduce various interventions to as-

${ }^{19}$ P. Grzelak, P. Kubicki, M. Orłowska, Realizacja badania ścieżek edukacyjnych niepetnosprawnych dzieci, uczniów i absolwentów - raport końcowy, Instytut Badań Edukacyjnych, Warszawa, 2014, p. 145.

20 P. Kubicki, "Między włączaniem a segregacją - szkoły w Polsce wobec uczniów z niepełnosprawnościami", Niepetnosprawność. Dyskursy Pedagogiki Specjalnej, no. 22, 2016, p. 110.

${ }^{21}$ A. Firkowska-Mankiewicz, G. Szumski, "Pedagogika specjalna i system kształcenia osób z niepełnosprawnościami w Polsce", [in:] Pedagogika specjalna, Vol. 2, D.D. Smith, Wydawnictwo Naukowe PWN, Wydawnictwo Akademii Pedagogiki Specjalnej, Warszawa, 2008, pp. 337-338. 
sist the comprehensive development of students with disabilities as well as, together with the general education teacher, plan and give classes and conduct rehabilitation activities. ${ }^{22}$

The number of students with disabilities in integrated classes and schools has been consistently growing since the 1990s, and the popularity of this form of education arises mainly from the declared availability of specialist interventions in the area of instruction, education, and rehabilitation with regular interactions with nondisabled peers. At present, about $24 \%$ of students with disabilities attend integrated settings, but these are rarely students with more severe impairments or with intellectual disabilities. ${ }^{23}$ Integrated settings' ongoing difficulties with providing students whose educational and developmental needs differ significantly from typical ones with full participation in class and school life become apparent in the study carried out by the Educational Research Institute, which reveals that $40 \%$ of integrated school principals recommended school transfer to parents as they were not able to provide appropriate support for the child, and $20 \%$ of schools did not enroll a student with disability. Sixty-one percent of integrated school principals admitted that students with disabilities sometimes transferred to special schools. ${ }^{24}$ Transfer to special school after a certain time, sometimes after a few years in integrated school (called "expulsion from integration" 25 ) entails a number of negative conse-

22 M. Pachowicz, “Kształcenie integracyjne - moda czy krok milowy edukacji w Polsce", [in:] Uczeń z niepetnosprawnościa w szkole ogólnodostępnej, Z. Gajdzica (Ed.), Oficyna Wydawnicza “Humanitas," Sosnowiec, 2011, p. 126.

${ }^{23}$ I. Chrzanowska, "Stan i rozmiary udziału dzieci i młodzieży z niepełnosprawnością w edukacji włączającej w Polsce", Forum Pedagogiczne, no. 1, 2016, pp. 41-42.

24 P. Kubicki, "Między włączaniem a segregacją - szkoły w Polsce wobec uczniów z niepełnosprawnościami", Niepetnosprawność. Dyskursy Pedagogiki Specjalnej, no. 22, 2016, p. 113.

${ }^{25}$ D. Krzemińska, "O edukacji (nie)integracyjnej kilka refleksji”, [in:] Szkoła dla osób z niepetnosprawnością. Wzory - Codzienność - Wyzwania, A. Krause, J. Belzyt, S. Sadowska (Eds.), Wydawnictwo Uniwersytetu Gdańskiego, Gdańsk, 2012, pp. 57-71. 
quences for students with disabilities who frequently have then very poor skills important to perform academic tasks, e.g. students with hearing impairments are not proficient at alternative methods of communication ${ }^{26}$ or blind students do not know non-visual reading or writing techniques. ${ }^{27}$

Although transition from segregated education to integrated education is considered a positive change expressing the practical implementation of the normalization principle, the demand for equal opportunity, and granting each student the right to quality education, ${ }^{28}$ the literature on the subject abounds with critical analyses pointing to certain imperfections of integrated education adopted in Poland. Most frequently, researchers ${ }^{29}$ list the following weak points of integrated education:

- difficulty with providing students who have varying disabilities with professional pedagogical assistance due to support teachers' educational background (they generally have specialist qualifications in one or two special education subfields);

26 P. Kowalski, D. Nowak-Adamczyk, “Kształcenie osób głuchych i słabosłyszących - wyzwania dla systemu edukacji w Polsce", Biuletyn Rzecznika Praw Obywatelskich. Źródła, no. 7, 2012, p. 69.

${ }^{27}$ K. Miler-Zdanowska, “Edukacja uczniów z niepełnosprawnością wzroku w Polsce - szanse, zagrożenia, wyzwania", [in:] Możliwości i ograniczenia edukacji inkluzyjnej. Egzemplifikacje, T. Zacharuk, L. Pytka (Eds.), Uniwersytet Przyrodniczno-Humanistyczny, Siedlce, 2018, p. 48.

${ }_{28}$ M. Kupisiewicz, “Paradygmaty pedagogiki specjalnej - główne kierunki przemian w Polsce w ostatnim trzydziestoleciu", Człowiek - Niepetnosprawność - Społeczeństwo, no. 2, 2006, p. 27.

${ }^{29}$ Cf. I. Chrzanowska, “Niepełnosprawny w szkole. Z analiz dotyczących kompetencji szkolnych i realizacji przez szkoły standardu stwarzania warunków zapewniających rozwój osobom niepełnosprawnym", [in:] Pedagogika specjalna. Różne poszukiwania - wspólna misja, Wydawnictwo Akademii Pedagogiki Specjalnej, Warszawa, 2009, pp. 384-397. Z. Ostrach, "Postrzeganie kształcenia integracyjnego przez rodziców uczniów pełnosprawnych", [in:] Uczeń z niepetnosprawnością w szkole ogólnodostępnej, Z. Gajdzica (Ed.), Oficyna Wydawnicza "Humanitas," Sosnowiec, 2011, pp. 132-141. M. Buchnat, "Sytuacja dzieci z lekką niepełnosprawnością intelektualną w klasach integracyjnych", [in:] Szkoła dla osób z niepetnosprawnością. Wzory - Codzienność - Wyzwania, A. Krause, J. Belzyt, S. Sadowska (Eds.), Wydawnictwo Uniwersytetu Gdańskiego, Gdańsk, 2012, pp. 163-182. 
- schools lack appropriate equipment, teaching and rehabilitation aids, textbooks in alternative formats, classroom environment is not adequately adapted;

- few rehabilitation activities and (or) rehabilitation activities are conducted by unqualified educators;

- relatively low sociometric status of children with disabilities in their peer group that suggests insufficient interventions to make the class more integrated;

- difficulty with practical implementation of the general education teacher-support teacher cooperation model (in consequence, the class is divided into two groups: nondisabled students and students with disabilities).

Integrated education as organized in Poland is an intermediate link between education in special schools and inclusive education in mainstream schools. This form of education sees a steady rise in the number of students with disabilities; however, there is growing criticism of this type of schooling, such as, for example, Paweł Kubicki's opinion: " (...) the fact itself that they [integrated schools and classes] still exist as a transitional form shows unfinished transformation because with appropriate support, integration in mainstream schools as it is now is no longer needed nor does it provide such specialist support for students with profound disabilities as special schools". ${ }^{30}$

The core idea of education for students with disabilities in mainstream schools is the demand for equal rights, according to which individual and social solutions are recommended that ensure all (regardless of their health and skill level) full participation in mainstream communal life, including access to educational institutions. Under Polish law, this group of students is provided with the possibility to receive compulsory education in a local school or a school that is situated near their place of residence, along with their non-

30 P. Kubicki, "Między włączaniem a segregacją - szkoły w Polsce wobec uczniów z niepełnosprawnościami", Niepetnosprawność. Dyskursy Pedagogiki Specjalnej, no. 22, 2016, p. 117. 
disabled peers. This educational form is not bound by organizational guidelines for integrated classes (fewer students in a class, constant presence of a special educator), but students with disabilities should be provided with appropriate psychoeducational support. At present, about $35 \%$ of students with disabilities receive inclusive education, and these are usually students with motor disabilities, low vision, ASD, chronic conditions, and hard-of-hearing students. ${ }^{31}$

The idea of "school for all", which expresses the recognition of diversity in children's and adolescents' academic abilities and needs as a norm and value, becomes a central category in the discourse on changes in the Polish system of special education. ${ }^{32}$ Although inclusive assumptions are considered reasonable, as they correspond fully to the current models of disability, researchers underline that conditions enabling successful inclusion of students with disabilities and a high quality of this process still have not been met in schooling practice. The study report produced by the Educational Research Institute showed significant differences between mainstream schools and special schools in the level of adaptations to school buildings, appropriate resources, and qualified staff. Among the mainstream schools taking part in the study, $69 \%$ did not hire a fulltime psychologist, $41 \%$ - a speech therapist, and $81 \%$ - support teachers (in line with the legislation, they have to be present only in integrated schools, while in mainstream schools, they may be hired with the approval of the governing body). ${ }^{33}$ The relatively small percentage of special educators hired in mainstream schools makes it difficult to provide appropriate support to the student with disa-

31 I. Chrzanowska, "Stan i rozmiary udziału dzieci i młodzieży z niepełnosprawnością w edukacji włączającej w Polsce", Forum Pedagogiczne, no. 1, 2016, pp. 41-42.

32 J.J. Błeszyński, “Włączanie (inkluzja) jako normalizacja systemu edukacji i opieki nad osobami niepełnosprawnymi", [in:] Pedagogika specjalna - tak wiele pozostaje dla nas tajemnica..., S. Przybyliński (Ed.), Wydawnictwo Uniwersytetu Warmińsko-Mazurskiego, Olsztyn, 2010, pp. 73-74.

33 P. Grzelak, P. Kubicki, M. Orłowska, Realizacja badania ścieżek edukacyjnych niepetnosprawnych dzieci, uczniów i absolwentów - raport końcowy, Instytut Badań Edukacyjnych, Warszawa, 2014, p. 123. 
bility, 34 especially as they generally do not have theoretical or practical qualifications to work with children and adolescents with varying disabilities, which is directly connected with the current teacher training system. ${ }^{35}$ A questionnaire survey conducted among teachers in mainstream, integrated, and special schools found that mainstream teachers were the ones who gave the lowest ratings to their qualifications for working with students with special educational needs. Almost 33\% of the respondents from this group described their qualification level as "low" and "very low", and $47.4 \%$ found it to be "quite good" or "good". None of the respondents in integrated and special schools put their skills of special education in the "low" or "very low" category. 36 It is also worth stressing that parents of students with disabilities who participated in the study conducted by the Educational Research Institute chose mainstream schools first of all because of their proximity to their place of residence, and $25 \%$ of them would prefer to have their child attend an integrated school, and 5\% - a special school. ${ }^{37}$ The need to undertake multifaceted actions aiming to improve the quality of education for students with disabilities within mainstream schooling, including expanding the scope of specialist assistance, is considered to be the main challenge for the educational system. Introducing a control system in schools and governing bodies in the area of the

34 Cf. A. Zamkowska, "Przygotowanie szkoły ogólnodostępnej do kształcenia uczniów upośledzonych umysłowo w stopniu lekkim", [in:] Aktualne problemy edukacji $i$ rehabilitacji osób niepetnosprawnych w biegu życia, Z. Palak, A. Bujnowska, A. Pawlak (Eds.), Wydawnictwo Uniwersytetu Marii Curie-Skłodowskiej, Lublin, 2010, p. 266.

35 Z. Janiszewska-Nieścioruk, “Aktualne preferencje edukacyjne uczniów o specjalnych potrzebach i ich konsekwencje", [in:] Szkoła dla osób z niepetnosprawnością. Wzory - Codzienność - Wyzwania, A. Krause, J. Belzyt, S. Sadowska (Eds.), Wydawnictwo Uniwersytetu Gdańskiego, Gdańsk, 2012, pp. 47-51.

${ }^{36}$ K. Ćwirynkało, A. Żyta, "Przekonania nauczycieli na temat edukacji włączającej uczniów ze specjalnymi potrzebami. Raport z badań", Szkoła Specjalna, no. 4, 2015, p. 256, DOI: 10.5604/0137818x.1177729.

37 P. Grzelak, P. Kubicki, M. Orłowska, Realizacja badania ścieżek edukacyjnych niepetnosprawnych dzieci, uczniów i absolwentów - raport końcowy, Instytut Badań Edukacyjnych, Warszawa, 2014, p. 103. 
Table 1. SWOT analysis of the educational system for students with disabilities in Poland. Source: Compiled by the authors

\begin{tabular}{|c|c|}
\hline Strengths & Weaknesses \\
\hline $\begin{array}{l}\text { - various forms of special education that } \\
\text { make it possible to choose an optimal so- } \\
\text { lution adapted to the individual situation } \\
\text { of a student with disability and his or her } \\
\text { family; } \\
\text { - regulations that protect the right to educa- } \\
\text { tion for students with disabilities and the } \\
\text { choice of the form of education for par- } \\
\text { ents; } \\
\text { - relatively large financial resources allocat- } \\
\text { ed from the state budget to support stu- } \\
\text { dents with disabilities; } \\
\text { - inclusive education is recognized as the } \\
\text { leading, recommended form of special } \\
\text { education }\end{array}$ & $\begin{array}{l}\text { - dominant trend for students with disabili- } \\
\text { ties transferring from mainstream or inte- } \\
\text { grated schools to special ones; } \\
\text { - architectural and mental barriers and lack } \\
\text { of or insufficient support in terms of spe- } \\
\text { cial education in mainstream and inte- } \\
\text { grated schools; } \\
\text { - relatively low involvement of parents of } \\
\text { students with disabilities in cooperation } \\
\text { with school, among others - in education } \\
\text { and therapy planning and implementa- } \\
\text { tion; } \\
\text { - limited access to integrated and special } \\
\text { education for rural students (seemingly } \\
\text { a "choice" of inclusive education); } \\
\text { - low satisfaction of the rehabilitation needs } \\
\text { of students with disabilities, in particular } \\
\text { of these with severe disabilities and rural } \\
\text { ones; } \\
\text { - relatively high number of students with } \\
\text { disabilities receiving individual instruc- } \\
\text { tion (the highest in mainstream schools) }\end{array}$ \\
\hline Chances & Risks \\
\hline $\begin{array}{l}\text { - to increase the participation of special } \\
\text { schooling in developing an integration } \\
\text { support base (e.g.: consulting units, cen- } \\
\text { ters of instructional adaptations, courses } \\
\text { and training for students, parents, and } \\
\text { teachers); } \\
\text { - opportunity to implement diverse proven } \\
\text { methods used in other countries to pro- } \\
\text { vide teachers and students with disabili- } \\
\text { ties with professional support, especially } \\
\text { in mainstream settings; } \\
\text { - technological advances, greater availabil- } \\
\text { ity of diverse rehabilitation and IT aids } \\
\text { that make education easier for students } \\
\text { with various impairments }\end{array}$ & $\begin{array}{l}\text { - local authorities attempting to shift re- } \\
\text { sponsibility onto foundations and associa- } \\
\text { tions conducting activities for the welfare } \\
\text { of children and adolescents with disabili- } \\
\text { ties; } \\
\text { - top-down obligation of inclusion without } \\
\text { appropriate systemic changes }\end{array}$ \\
\hline
\end{tabular}


practical implementation of the legislation ensuring students with disabilities professional support is regarded as one of the key actions. ${ }^{38}$

To sum up, the Polish system of special education includes different organizational forms and the regulations introduced protect the right of students with disabilities to education that takes into consideration their individual needs and abilities. As Anna Firkowska-Mankiewicz and Grzegorz Szumski point out, the existing system "is not a modern system yet. However, unlike systems in many other countries, it has been recently undergoing visible modernization (...). Reforms implemented in special education after 1989 had good aims and as a general rule, appropriate strategies were chosen to fulfill them". ${ }^{39}$ Undoubtedly, the gradual shift from the dominance of segregated education toward full inclusion of people with disabilities in mainstream schooling should be regarded as a positive fact. However, the serious negligence revealed in research in terms of meeting the special educational needs of students in mainstream schools indicates an urgent need for remedial measures.

\section{Education for students with disabilities in Hungary}

Disability rights were composed in Hungary for the first time in an act called "Act No. 26 of 1998 on assuring equal opportunity for people with disabilities". It provides equal opportunities for people with disabilities in health care services, education, employment as well as in cultural and sports activities. It makes provision for the right to rehabilitation and financial aid. It laid down the establishment of the National Council and National Program for Disabled

38 P. Wdówik, „Podręczniki i pomoce dydaktyczne dla uczniów z niepełnosprawnościami”, Biuletyn Rzecznika Praw Obywatelskich. Źródła, no. 7, 2012, pp. 86-87.

39 A. Firkowska-Mankiewicz, G. Szumski, „Pedagogika specjalna i system kształcenia osób z niepełnosprawnościami w Polsce”, [in:] Pedagogika specjalna, Vol. 2, D.D. Smith, Wydawnictwo Naukowe PWN, Wydawnictwo Akademii Pedagogiki Specjalnej, Warszawa, 2008, p. 346. 
Affairs. The act has been modified several times since 1998. "This act declares the equality of rights in all areas of social life and education for people included within the scope of the act and bans negative discrimination against them and, where it is absolutely necessary, allows positive discrimination". ${ }^{40}$ Hungary signed the United Nations Convention on the Rights of Persons with Disabilities (CRPD) and the CRPD-OP - Optional Protocol on the Rights of Persons with Disabilities in 2006, ${ }^{41}$ which were ratified by Hungary in 2007.

“CRPD, Article 3, General Principles

1. Respect for inherent dignity, individual autonomy including the freedom to make one's own choices, and independence of persons

2. Non-discrimination

3. Full and effective participation and inclusion in society

4. Respect for difference and acceptance of persons with disabilities as part of human diversity and humanity

5. Equality of opportunity

6. Accessibility

7. Equality between men and women

8. Respect for the evolving capacities of children with disabilities and respect for the right of children with disabilities to preserve their identities". 42

The CRPD and CRPD-OP ratification had a positive impact on the Hungarian legislation, which was later followed by a change of the whole legislation system in Hungary, starting with a new Constitution. The new Hungarian Constitution is called Fundamental Law of Hungary. ${ }^{43}$ It guarantees everyone the fundamental rights

${ }^{40} \mathrm{~K}$. Kovács, Empowerment of students with disabilities in university settings, In Inclusion, equity and access for individuals with disabilities, S. Halder, V. Argyropoulos (Eds.), Insights from Educators across World. Palgrave, 2019. p. 594.

41 United Nations Convention on the Rights of Persons with Disabilities (CRPD) and Optional Protocol, UN. 2006.

42 Guiding Principles of the Convention (CRPD), 2006 UN.

43 Magyarország Alaptörvénye, Igazságügyi Minisztérium, 2017 [accessed: 01.12.2019]. 
without discrimination on the grounds of race, color, gender, disability, language, religion, political or other beliefs, national or social origin, property, birth or any other status.

The 1993 Act on Public Education introduced the initiative for integrated mainstream education for students with disabilities and special educational needs (SEN) in Hungary. Since 1993, fundamental changes have taken place in the Hungarian education system in response. During the nineties, there was a rapid increase in the number of students with special needs studying near their home in local or nearby schools. According to governmental sources, these changes led to a growing inequity indicated by international indicators at all levels of education. "In spite of modernization efforts, basic structural characteristics - mainly the high level of decentralisation - established by the 1993 Act on Public Education proved to be an obstacle to equity. The main problem was that municipalities had to maintain the schools for which the transfer from the central budget was insufficient, and many of the smaller municipalities could not contribute from their own resources. Inequalities grew and teacher salaries became uncompetitive compared to the income of other professionals". ${ }^{4}$

Since 2010, following the new Fundamental Law, all acts have been affected, including the National Public Education Act and Higher Education Act. ${ }^{45}$ "Act 190 (CXC) of 2011 on Public Education laid down the framework for a centralized system of public education. The three main elements of the new act concern organization and funding of education, a new remuneration and career scheme for teachers, and the establishment of a quality assurance system in the form of a network of school inspectors recruited from the teaching force active in schools". ${ }^{46}$

44 J. Kádár-Fülöp, J. Lannert (Eds.) Public Education in Hungary: Facts and Figures 2014/2015 p. 2.

45 1993. évi LXXX törvény a felsőoktatásról.

46 J. Kádár-Fülöp, J. Lannert (Eds.) Public Education in Hungary: Facts and Figures 2014/2015 p. 2. 
Although there are many similarities between the Polish and Hungarian educational systems for children with disabilities/SEN as noted before, it seems to be essential to provide a description of the national content for better orientation. According to Act 190 (CXC) of 2011, clause 4, § 25 on National Public Education, students with special educational needs are those who, based on the expert opinion of the Committee of Experts, require special treatment, have physical, sensory (visual or auditory), intellectual or speech impairments, autism spectrum disorders or other psychiatric disorders or developmental disorders (severe learning difficulties, attention deficits or behavior issues).

It seems to be essential to start with some theoretical and (or) practical issues of the meaning of integration/inclusion as we think about them in Hungary. Papp ${ }^{47}$ argues that the two expressions are not synonyms of each other. Authors do not use the words consistently internationally. "The tendency to move from integration to inclusion is obviously less related to a shift in content than to a change in language, simply referring to the concept of inclusion of the Salamanca declaration and explanation". ${ }^{48}$ Inclusion is an idea in education. All educational systems are pursuing it. This requires a fundamental change - a new school concept. "Such a school is open to natural diversity among students and mutual adaptation to differences is expected. It is a school where the interpretation of learning is based on the individual's learning strategies, where the special education teacher and the general education teacher jointly control the process". ${ }^{49}$ In an inclusive school, the heterogeneous

${ }^{47}$ G. Papp, “Az integráció, inklúzió fogalmak tartalmi elemzése gyógypedagógiai megközelítésben nemzetközi és magyar színtéren”, Gyógypedagógiai Szemle, no. 4, 2012, pp. 295-304.

48 G. Papp, “Az integráció, inklúzió fogalmak tartalmi elemzése gyógypedagógiai megközelítésben nemzetközi és magyar színtéren”, Gyógypedagógiai Szemle, no. 4, 2012, p. 296.

${ }^{49}$ G. Papp, “Az integráció, inklúzió fogalmak tartalmi elemzése gyógypedagógiai megközelítésben nemzetközi és magyar színtéren”, Gyógypedagógiai Szemle, no. 4, 2012, p. 297. 
group of students and the individual characteristics of the student community are in the focus regardless of ethnicity, abilities, etc. Integration means to put originally separated parts together. ${ }^{50}$ In 2004, Réthyiné proposed a change of paradigm from previous school strategies and practices arguing that the organizational framework for inclusive school services is based on the principle of heterogeneity. 51,52

The 2003 amendment of the Public Education Act ${ }^{53}$ allowed establishing Unified Special Education Methodological Institutions (EGYMI) from the former special education schools. The task was to support education for children with special needs in integrated settings. The services offered by EGYMI included: counselling, early development and care, development support/training, speech therapy, conductive pedagogical care, and physical education. Among professional services, they could provide professional counselling, educational information, support and organization of teachers' self-education and training as well as student information and counselling services. As part of the parallel processes shaping the legislative framework in accordance with the Fundamental Law, Act 190, Article $20(9)^{54}$ changed the role of EGYMI. This was followed by an amendment ${ }^{55}$ in 2013 which separated the institution of Pedagogical Specialist Service from the tasks of EGYMI.

Following Act 190, the tasks of EGYMI radically changed. Two separate institutions were established all over the country, although

50 A. Varga, Az inklúzió szemlélete és gyakorlata. Pécsi Tudományegyetem Bölcsészettudományi Kar Neveléstudományi Intézet Romológia és Nevelésszociológia Tanszék Wlislocki Henrik Szakkollégium Pécs, 2015.

${ }^{51}$ E. Réthy, Inkluzív pedagógia, In Megközelitések, I. Nahalka, J. Torgyik (Eds.), Eötvös Könyvkiadó, Budapest, 2004, p. 231-245.

52 E. Réthy, Befogadás, méltányosság, az inkluzív pedagógia rendszere. Comenius Oktató és Kiadó Kft., 2013 Pécs.

53 2003. évi LXI. törvény - a közoktatásról szóló 1993. évi LXXIX. törvény módosításáról.

54 2011. évi CXC. törvény a nemzeti köznevelésről.

55 15/2013. (II. 26.) EMMI rendelet a pedagógiai szakszolgálati intézmények múködéséról. 
the two work under one roof or under EGYMI in some organizations but as separate functional organizations. The committee is in charge of specialist assessments and, together with parents, can decide on the educational placement of the child with SEN. At the same time, some other service provisions were also moved to this institution unexpectedly:

- special education counselling, early development, and care,

- development support,

- activities of the Committee of Experts,

- educational advice,

- speech therapy,

- continuing education, career guidance,

- conductive pedagogical care,

- physical education,

- school psychology, kindergarten psychology,

- care for gifted and talented students. 56

The characteristics of teacher training in Hungary are as follows: "Teacher training in elementary education includes eight semesters of higher education courses leading to a bachelor's degree. Teachers for elementary grades are trained to teach all subjects at the Grade 1 to 4 level and they may specialize in some subjects which they can teach up to Grade 6". ${ }^{57}$ Special education teachers qualify for teaching children with special educational needs and they get a dual specialization in full time studies (study to teach two populations with $\mathrm{SEN})$. The training for them is also eight semesters at the BA level, which can be then followed with three semesters of MA studies with another specialization, e.g. remedial teaching. There is one Faculty of Special Needs Education (BGGYK) at Eötvös University which offers training in all populations and since 2010, other universities in different parts of the country have been also offering tertiary education for teacher training in one or two populations

56 15/2013. (II. 26.) EMMI rendelet a pedagógiai szakszolgálati intézmények múködéséról.

57 J. Kádár-Fülöp, J. Lannert (Eds.), Public Education in Hungary: Facts and Figures 2014/2015 p. 30. 
with SEN, typically for intellectual disabilities, speech-language disorders, and emotional and behavior problems. Since 2017, seven other universities have been involved in special education teacher training. The BGGYK has opened an extension in eastern Hungary at the University of Nyiregyhaza, offering part-time programs in two SEN populations: intellectual disabilities and speech-language disorders. All these developments, however, still cannot cover the need for special education teachers in the country.

After 1993, the rapid increase of integrated education in mainstream institutions was unexpected to most of special schools and even more for the professionals working there. This was presumably a stronger reaction than in Poland because the number of special schools was higher in Hungary. As far as the number of special schools is concerned, statistical data based on the European Agency for Special Needs and Inclusive Education $2014^{58}$ show that Hungary was the $5^{\text {th }}$ in the list of European countries while Poland was the $13^{\text {th }}$. In contrast, the number of children involved in mainstream education was almost on the same level, i.e. around $98 \%$.

Special education institutions faced two important consequences: the number of students in special schools started to decrease while rising in integrated settings. A new professional field opened for special schools to utilize their knowledge and expertise of special education in pedagogical support for students in mainstream education. Special schools started to act as resource centers and carried out pedagogical service activities. This had a two-sided effect: made it possible to survive among integrated settings and offered opportunities for renewal, extending professional competences, and becoming engines of widespread collaboration. As mentioned before, the 2003 amendment of the Public Education Act ${ }^{59}$ finally created the legal background to expand the role of special

58 European Agency for Special Needs and Inclusive Education, 2017. European Agency statistics on inclusive education: 2014 dataset cross-country report. (J. Ramberg, A. Lénárt, A. Watkins, Eds.). Odense, Denmark.

${ }^{59}$ 2003. évi LXI. törvény - a közoktatásról szóló 1993. évi LXXIX. Törvény módosításáról. 
education institutions. The law allowed establishing the Unified Special Education Methodological Institutions (EGYMI) from the former special schools. The task was to support education for children with special needs in integrated settings. The services offered by EGYMI included: counselling, early development and care, development support/training, speech therapy, conductive pedagogical care, and physical education. Among professional services, they could provide professional counselling, educational information, support and organization of teachers' self-education and training as well as student information and counselling services. Although the network of Pedagogical Specialist Service and the Committee of Experts existed since the eighties, EGYMI incorporated these tasks.

In 2004, Hungary joined the European Union. The European Union tenders have encouraged large-scale cooperation between mainstream and special schools. Applicant consortia were in most cases led by special schools. The focus of the activities was on expanding the range of pedagogical professional services. In 2005, 15\% of former special schools transformed into EGYMI and 39\% were under transformation. This could be considered a major achievement and resulted in more and more teachers and parents receiving professional support for the successful education of children with disabilities and typically developing children together. At that time, EGYMI served as a means of preparing for knowledge transfer and other tasks for inclusive education.

Although the network was making progress then, the services offered by EGYMI were of variable quality and composition. The type of services they were allowed to provide was essentially dependent on the authority they were run by. At that time, EGYMI belonged to the local governments of their municipalities. After 2009, as the economic crisis deepened, inequalities in services became even more significant. Some of EGYMI could provide good working conditions while there were areas where even the tasks required by law were not fulfilled. As mentioned before, as part of the parallel processes shaping the legislative framework, the responsibilities of this type of institution were changed in the 2011 
Act 19060: "EGYMI can be set up to help educate children and students with special educational needs together with other children and students. In accordance with their objectives, EGYMI may carry out pedagogical service tasks in addition to the tasks of the Committee of Experts. They can also provide family support services, school health services, and work within an institution such as a kindergarten, elementary or secondary school. The functions of EGYMI shall be the subject of separate institutional and professional units". ${ }^{61}$ Although EGYMI could continue the pedagogical service task, it was separated from their basic role and not all of EGYMI could provide the necessary conditions for the Expert Committee any more in line with the amendment made in 2013. In the 2013 amendment, 62 the activities of the Pedagogical Specialist Service (PSS) were regulated. The task of the PSS was briefly described above. The structure of PSS centers is explained here. The PSS network is built up on the administrative system of Hungary. The PSS network consists of at least one member institution per district in each county and in the capital. The center in the capital has sub centers for two reasons. One is that approximately $1 / 5$ of the country's population lives in the capital. The other is that some of these institutions need such a level of expertise that there is only one serving the whole country and this one specialist center is located in the capital, e.g. Specialized Pedagogical Service Center for Physical Disabilities as part of the Metropolitan Pedagogical Service Center. The Metropolitan Pedagogical Service Centre has 33 member institutions and there are similar specialist sub centers for speech-language, hearing, and visual impairments. The same organizational and operational rules apply to all member institutions in the whole country.

The activity of the Unified Special Educational Methodological Institutions (EGYMI) has changed significantly as partly described

60 2011. évi CXC. törvény a nemzeti köznevelésről.

61 2011. évi CXC. törvény a nemzeti köznevelésről.

62 15/2013. (II. 26.) EMMI rendelet a pedagógiai szakszolgálati intézmények múködéséről. 
before. "the specialized services within EGYMI, they were transformed into county service centers. It was not stress-free because EGYMI lost the functions which have been carried out over the last ten years. Early childhood education, special education, and speech therapy are the three areas that have been affected most here. Most importantly, the itinerant special education network is now run by EGYMI (...). Their operation is professionally justified there" ${ }^{\prime 6}$ There are still difficulties in these areas of the country which have no EGYMI and because of this, educational support for mainstream schools is not necessarily provided all over the country. The educational authority's resolution is that all educational institutions can employ special education teachers to support students with SEN directly. Furthermore, it is emphasized that the activity of EGYMI is not limited to administrative areas but overlaps county borders. In the daily practice, it is also common that special education teachers are part-time employees of local schools or are hired by EGYMI to serve schools within their locality if that school is integrating a student with SEN within the specialization of a given special education teacher, e.g. visual impairment. Since 2011, according to the law, institutions involved in special education, whether integrated or segregated, must have special education teachers with appropriate specializations.

An additional difficulty is the wide professional area these institutions are supposed to cover. Their services include diagnostic and rehabilitation services to establish special education needs and to provide therapy for all levels of public education. The most important of these are SEN diagnostic and rehabilitation services, institutions for children with severe disabilities, including early intervention and care, speech therapy and conductive pedagogy services, physiotherapy, and light physical exercises. SEN Diagnostic and Rehabilitation Committees are multi-professional bodies of

63 “A jogszabályon kívül idővel kicserélődnek a jó gyakorlatok" 2014 https://www.oktatas.hu/kozneveles/projektek/tamop3110_oktatasiranyitas/projek thirek/kiss_laszlo_sni_nevelesrol?printMode=true. 
special educators, teachers, psychologists, and physicians. Diagnosing special educational needs requires close cooperation between parents, educators, SEN professionals, physicians, and social workers. The Committee is responsible for establishing whether a child or student should be transferred to a special kindergarten or school, or whether he or she needs early intervention and care or individual tutoring. This body is also consulted in cases when a child is advised by the kindergarten teacher - or if it is requested by the parent - to delay school entry for more than one year. Early intervention and care refers to an early diagnosis of delayed development in children below 3 years of age and children with multiple impairments. The services include support to families in childcare as well as providing access to special education institutions. More than two thirds of children diagnosed in early intervention and care programs need individual tutoring. One in four children is provided with services by private entities. Children with severe and multiple disabilities are provided for by special institutions. "About $25 \%$ of these institutions are run by private entities and they provide tutoring to $40 \%$ of the children in need (...). The development of skills in the case of challenges such as dyslexia, dyscalculia, etc., is organized in group form locally and through itinerant speech therapists to reach all students. Light physical exercises and physiotherapy are organized in bigger schools in such a way that students from other schools can attend the classes as well".64

"Children with special educational needs are provided for within early intervention care or special kindergarten units depending on their special needs. Also, they have access to specific services of early development. These services are organized at the county level". 65 Additional financial support is given to these institutions for children with SEN. There are governmental and various private

64 J. Kádár-Fülöp, J. Lannert (Eds.), Public Education in Hungary: Facts and Figures 2014/2015 p. 32.

65 J. Kádár-Fülöp, J. Lannert (Eds.), Public Education in Hungary: Facts and Figures 2014/2015 p. 20. 
solutions offered for providing early intervention for children with SEN. The following table shows the number of children provided with services by different service providers jointly in 2009-2013 based on the data from Facts and Figures. ${ }^{66}$

Table 1.

Daycare facilities and family daycare units (private) for children with special educational needs

\begin{tabular}{|l|c|c|c|c|c|}
\hline Year & 2009 & 2010 & 2011 & 2012 & 2013 \\
\hline Number & 24767 & 31070 & 33805 & 34821 & 35664 \\
\hline
\end{tabular}

The last published Facts and Figures analysis shows the number of SEN students taking part in mainstream or special education. According to this document: "Students with special educational needs are mostly integrated in mainstream schools where they have access to specialist services (...); a network of special schools functions in parallel to mainstream schooling for children with specific disabilities, including severe and multiple disabilities". 67 "About 7\% of all students have special educational needs. Two thirds of these students were integrated in mainstream classes (4.8\%) and $2.3 \%$ were taught in special classes in 2014".68

According to the most recent data for 2019, the number of children in elementary schools is 726000 . There are 55300 students with SEN. As many as $71.1 \%$ of them attend mainstream settings; the remaining $28.9 \%$ - special schools. ${ }^{69}$ The number of students edu-

66 J. Kádár-Fülöp, J. Lannert (Eds.), Public Education in Hungary: Facts and Figures 2014/2015 p. 25.

67 J. Kádár-Fülöp, J. Lannert (Eds.), Public Education in Hungary: Facts and Figures 2014/2015 p. 26.

68 J. Kádár-Fülöp, J. Lannert (Eds.), Public Education in Hungary: Facts and Figures 2014/2015 p. 28.

${ }^{69}$ Eduline https://eduline.hu/kozoktatas/20190109_tanulok_es_pedagogusok_ szama 
cated in self-contained classrooms in local schools has decreased. The number of students with SEN is the lowest in the eastern county of Hajdú-Bihar (4.7\%), while the highest is in Bács-Kiskun county in the south-central part of the country $(13.3 \%)$. There are significant differences between counties in the level of mainstreaming. While it is $82.9 \%$ in the north-western part in Györ-Moson-Sopron county, it is only $56.8 \%$ in the capital. ${ }^{70}$ In kindergartens, children with SEN constitute $3.0 \%$ of the whole population and $82.2 \%$ are in mainstream settings.

Table 2.

\begin{tabular}{|l|c|c|c|c|c|}
\hline \multicolumn{7}{|c|}{ Number of students in elementary education (2009-2014) } \\
\hline $\begin{array}{l}\text { Total number of full-time stu- } \\
\text { dents in elementary education }\end{array}$ & 773706 & 756569 & 747601 & 742931 & 747746 \\
\hline $\begin{array}{l}\text { Percentage of students with SEN } \\
\text { integrated in mainstream classes }\end{array}$ & 4.6 & 4.7 & 4.8 & 4.8 & 4.9 \\
\hline $\begin{array}{l}\text { Percentage of students with SEN } \\
\text { in special schools/classes }\end{array}$ & 3.0 & 2.8 & 2.7 & 2.5 & 2.4 \\
\hline
\end{tabular}

At a statistical level, there is a great improvement in mainstream education in Hungary. This is consistent with practical experiences, e.g. in the school for blind children in Budapest, the number of children is lower than $1 / 3$ of the number of children before 1993. The tendency is that children with visual impairments without additional disabilities or with mild and moderate visual disabilities are easily integrated into local schools. Special schools are facing a great challenge of serving children with severe multiple disabilities. Formerly, these children were educated in their homes within programs called "developmental education." This is a type of education

70 Oktatási adatok 2018/2019. Statisztikai tükör. KSH. http://www.ksh.hu/ docs/hun/xftp/idoszaki/oktat/oktatas1819.pdf

${ }^{71}$ J. Kádár-Fülöp, J. Lannert (Eds.), Public Education in Hungary: Facts and Figures 2014/2015 p. 29. 
guaranteed by law for children with severe multiple impairments for whom there are not any or not enough schools or institutions in the country. The percentage of those who get individual support is $38.8 \%$. The number of schools and support services is not given globally in any of the resources. Luckily, the number of special education teachers has increased from 5700 in 2010 to 9582, but still not filling all needs. This number is not enough to serve all children with SEN in mainstream settings at all educational levels or those in developmental education. The number of special educators and teachers at all levels of education has been decreasing in previous years, which is a heavy burden for education in Hungary in general. This tendency has many reasons rooted in societal characteristics.

Schooling starts in preschool for children at the age of 3 . There was a soft rule till 2019 to start preschool schooling later if the family had reasons for that - or due to the child's other conditions. Since 2019, the regulation has changed and all children who are born each year before August 31 have to start preschool schooling at the age of 3 . It is very strictly regulated who can be an exception. Special education professionals together with parents of children with SEN are fighting to change this regulation, which lowers the quality and length of early intervention support.

The law assures that institutions involved in special education, whether integrated or segregated, must have special education teachers with appropriate special education background. This goal has not been reached yet. Without it, the quality of mainstream education can be questioned. There is a strong need to increase the number of itinerant teachers in the whole country for special populations, e.g. sensory impairments, and special educators employed by local schools in general.

We translate inclusion as "affiliation" and integration as "placement" in Hungarian. The direction of the two is oppositional. While inclusion is under development, integration is a practice which still needs improvement as it was described. Integration has been typical in the Hungarian education system since 1993, although there were examples of integration even before 1993 and there have 
been a few inclusive schools, e.g. Gyermekek Háza72 as a good practice since the nineties. Csányi argues: "Institutions hosting students are mostly non-inclusive, and in some cases, simple name changes have taken place (...) without changing the content."73 There is still a lot to do to complete integrated education and a longer way towards inclusive education. The situation is illustrated by SWOT below:

Table 3. SWOT analysis of the educational system for students with disabilities in Hungary

\begin{tabular}{|l|l|}
\hline \multicolumn{1}{|c|}{ Strengths } & \multicolumn{1}{c|}{ Weaknesses } \\
\hline Legislative background & Lack of professionals \\
\hline $\begin{array}{l}\text { Well-trained professionals in special } \\
\text { education }\end{array}$ & $\begin{array}{l}\text { Some schools have no access to support } \\
\text { - no EGYMI nearby }\end{array}$ \\
\hline $\begin{array}{l}\text { Special schools transforming into sup- } \\
\text { port centers - EGYMI }\end{array}$ & $\begin{array}{l}\text { Special equipment is often missing, e.g. } \\
\text { in the case of visual impairment }\end{array}$ \\
\hline \multicolumn{1}{|c|}{ Opportunities } & \multicolumn{1}{c|}{ Threats } \\
\hline $\begin{array}{l}\text { Increased number of special education } \\
\text { students }\end{array}$ & $\begin{array}{l}\text { Low finances for equipment and service } \\
\text { delivery }\end{array}$ \\
\hline $\begin{array}{l}\text { Openness and need for support in local } \\
\text { schools }\end{array}$ & $\begin{array}{l}\text { Number of teachers decreasing, includ- } \\
\text { ing special teachers }\end{array}$ \\
\hline
\end{tabular}

\section{Conclusions}

In Poland and Hungary, a steady growth trend in the number of students with disabilities attending mainstream settings is seen as well as marked changes within the population of students in special schools, i.e. decrease in the total number of students in special schools and increase in the number of students with multiple disa-

72 Gyermekek Háza https://gyermekekhaza.hu/about-us/_15/2013. (II. 26.) EMMI rendelet a pedagógiai szakszolgálati intézmények múködéséről.

${ }^{73}$ Y. Csányi, "Integráció/inklúzió és a szakvéleményezés összefüggései", Gyógypedagógiai Szemle 2013(3), pp. 165-173. 
bilities. In both educational systems - in line with the principles of the social model of disability - main interventions focus on getting rid of any barriers that increase the risk of excluding a student due to his or her health and skill level. With this end in view, various solutions are being introduced as part of which students with disabilities receive educational offers that provide for their special, individual developmental needs relating to the type and severity of disability among others. The two countries have adopted regulations that properly secure the right to education in non-segregated settings for students with disabilities; however, they are still struggling with providing this group of students with appropriate rehabilitation services and quality education. Both systems lack sufficient methodological support for teachers working with students with disabilities on a daily basis in mainstream settings as well as direct rehabilitation support from special educators and other specialists, although the complex factors determining these problems seem to be different. While the reasons for these difficulties in Hungary are sought first of all in the unavailability of specialist support in some regions of the country due to the location of assistance institutions and the decrease in the number of teachers, including special educators, in Poland, the root cause seems to lie in the current training system for teachers and special educators that is not adapted to the requirements of inclusive education and insufficient use of special schools' resources to support general education settings in work with students with disabilities. At present, both countries are confronted with the need to develop systemic changes that will allow introduction of strategies to meet students' special educational needs in each type of educational setting and at each level of education in a more efficient way.

References

Al-Khamisy D., "Kształcenie uczniów ze specjalnymi potrzebami edukacyjnymi w powszechnym systemie oświatowym", [in:] Dydaktyka specjalna w przygotowaniu do kształcenia uczniów ze specjalnymi potrzebami edukacyjnymi, J. Głodkow- 
ska (Ed.), Wydawnictwo Akademii Pedagogiki Specjalnej, Warsaw, 2012, pp. 113-139.

Błeszyński J.J., "Włączanie (inkluzja) jako normalizacja systemu edukacji i opieki nad osobami niepełnosprawnymi", [in:] Pedagogika specjalna - tak wiele pozostaje dla nas tajemnica..., S. Przybyliński (Ed.), Wydawnictwo Uniwersytetu Warmińsko-Mazurskiego, Olsztyn, 2010, pp. 65-75.

Buchnat M., "Sytuacja dzieci z lekką niepełnosprawnością intelektualną w klasach integracyjnych", [in:] Szkoła dla osób z niepetnosprawnością. Wzory - Codzienność Wyzwania, A. Krause, J. Belzyt, S. Sadowska (Eds.), Wydawnictwo Uniwersytetu Gdańskiego, Gdańsk, 2012, pp. 163-182.

Ćwirynkało K., Żyta A., "Przekonania nauczycieli na temat edukacji włączającej uczniów ze specjalnymi potrzebami. Raport z badań", Szkoła Specjalna, no. 4, 2015, pp. 245-259, DOI: 10.5604/0137818x.1177729.

Chrzanowska I., "Niepełnosprawny w szkole. Z analiz dotyczących kompetencji szkolnych i realizacji przez szkoły standardu stwarzania warunków zapewniających rozwój osobom niepełnosprawnym", [in:] Pedagogika specjalna. Różne poszukiwania - wspólna misja, Wydawnictwo Akademii Pedagogiki Specjalnej, Warsaw, 2009, pp. 384-397.

Chrzanowska I., Pedagogika specjalna. Od tradycji do współczesności, Oficyna Wydawnicza "Impuls", Cracow, 2015.

Chrzanowska I., "Stan i rozmiary udziału dzieci i młodzieży z niepełnosprawnością w edukacji włączającej w Polsce", Forum Pedagogiczne, no. 1, 2016, pp. 37-56.

Chrzanowska I., "Uczeń z niepełnosprawnością w różnych formach edukacji", [in:] W poszukiwaniu indywidualnych dróg wspierających wszechstronny rozwój osób z niepetnosprawnościa, B. Szczupał, A. Giryński, G. Szumski (Eds.), Wydawnictwo Akademii Pedagogiki Specjalnej, Warsaw, 2015, pp. 205-214.

Csányi Y., "Integráció/inklúzió és a szakvéleményezés összefüggései", Gyógypedagógiai Szemle, (3), 2013 pp. 165-173.

Czerwińska K., "Edukacja inkluzyjna uczniów z niepełnosprawnością wzroku" [in:] Edukacja inkluzyjna. Teoria - system - metoda. Część 1, S. Sobczak, L. Pytka, T. Zacharuk (Eds.), Uniwersytet Przyrodniczo-Humanistyczny, Siedlce, 2015, pp. 83-104.

Ćwirynkało K., Wójcik M., "Integracja osób pełno- i niepełnosprawnych jedną z dróg rozwoju kształcenia specjalnego", [in:] Uczeń z niepetnosprawnościa w szkole ogólnodostępnej, Z. Gajdzica (Ed.), Oficyna Wydawnicza "Humanitas", Sosnowiec, 2011, pp. 113-123.

Firkowska-Mankiewicz A., Szumski G., "Pedagogika specjalna i system kształcenia osób z niepełnosprawnościami w Polsce", [in:] Pedagogika specjalna, Vol. 2, D.D. Smith, Wydawnictwo Naukowe PWN, Wydawnictwo Akademii Pedagogiki Specjalnej, Warsaw, 2008, pp. 319-346.

Gajdzica Z., "Komparatystyka jako dział wiedzy pedagogiki specjalnej", [in:] Edukacja $i$ wsparcie społeczne osób z niepetnosprawnością w wybranych krajach europejskich, 
J. Wyczesany, Z. Gajdzica (Eds.), Oficyna Wydawnicza “Impuls," Cracow, 2005, pp. $25-43$.

Głodkowska J., "Uczniowie ze specjalnymi potrzebami edukacyjnymi - integracja edukacyjna procesem złożonym i trudnym", Szkoła Specjalna, no. 1, 2013, pp. 5-16.

Grzelak P., Kubicki P., Orłowska M., Realizacja badania ścieżek edukacyjnych niepetnosprawnych dzieci, uczniów i absolwentów - raport końcowy, Instytut Badań Edukacyjnych, Warsaw, 2014.

Gyermekek Háza https://gyermekekhaza.hu/about-us/ 15/2013. (II. 26.) EMMI rendelet a pedagógiai szakszolgálati intézmények múködéséról [01.12.2019]

Janiszewska-Nieścioruk Z., "Aktualne preferencje edukacyjne uczniów o specjalnych potrzebach i ich konsekwencje", [in:] Szkoła dla osób z niepetnosprawnością. Wzory - Codzienność - Wyzwania, A. Krause, J. Belzyt, S. Sadowska (Eds.), Wydawnictwo Uniwersytetu Gdańskiego, Gdańsk, 2012, pp. 45-56.

Janiszewska-Nieścioruk, Z., Zaorska M., "Prowłączające zmiany w systemie polskiej edukacji - nowe możliwości, ograniczenia i wyzwania", Interdyscyplinarne Konteksty Pedagogiki Specjalnej, no. 4, 2014, pp. 9-28.

Kádár-Fülöp J., Lannert J. (Eds.) Public Education in Hungary: Facts and Figures. This publication is based on the publication Facts and Figures of the Hungarian Education System developed in 2014 as part of the EU development program (TÁMOP-3.1.8-09/1-2010-0004 - “Programme for General Quality Development in Public Education" (c) T-tudok Zrt. 2016 https://www.t-tudok.hu/ files/2/facts_and_figures_210x210mm_angol_14-15-3.pdf

Kiss L., "Fogyatékkal élő és krónikus beteg hallgatók a felsőoktatásban”, “Felsőoktatási Múhely" 2014, no. 8 (1), pp. 117-128.

Kowalski P., Nowak-Adamczyk, D., "Kształcenie osób głuchych i słabosłyszących wyzwania dla systemu edukacji w Polsce", Biuletyn Rzecznika Praw Obywatelskich. Źródta, no. 7, 2012, pp. 61-72.

Kovács K., "Empowerment of students with disabilities in university settings", [in:] Inclusion, equity and access for individuals with disabilities, S. Halder, V. Argyropoulos (Eds.), Insights from Educators across World. Palgrave, 2019. p. 594.

Krzemińska D., "O edukacji (nie)integracyjnej kilka refleksji", [in:] Szkoła dla osób z niepetnosprawnościa. Wzory - Codzienność - Wyzwania, A. Krause, J. Belzyt, S. Sadowska (Eds.), Wydawnictwo Uniwersytetu Gdańskiego, Gdańsk, 2012, pp. 57-71.

Kubicki P., "Między włączaniem a segregacją - szkoły w Polsce wobec uczniów z niepełnosprawnościami", Niepetnosprawność. Dyskursy Pedagogiki Specjalnej, no. 22, 2016, pp. 107-118.

Kulesza E. M., (Ed.), Education of students with special needs. World experience. Individualized Education and Therapy Programs (IETPs), Wydawnictwo Akademii Pedagogiki Specjalnej, Warsaw, 2013. 
Kupisiewicz M., "Paradygmaty pedagogiki specjalnej - główne kierunki przemian w Polsce w ostatnim trzydziestoleciu", Człowiek - Niepetnosprawność - Społeczeństwo, no. 2, 2006, pp. 23-32.

Marcinkowska B., "Kształcenie uczniów z niepełnosprawnością w Polsce - przeszłość, teraźniejszość, przyszłość", Psychologia Wychowawcza, no. 7, 2015, pp. 205-219.

Miler-Zdanowska K., "Edukacja uczniów z niepełnosprawnością wzroku w Polsce szanse, zagrożenia, wyzwania", [in:] Możliwości i ograniczenia edukacji inkluzyjnej. Egzemplifikacje, T. Zacharuk, L. Pytka (Eds.), Uniwersytet PrzyrodnicznoHumanistyczny, Siedlce, 2018, pp. 39-53.

Oktatási adatok 2018/2019. Statisztikai tükör. KSH. http://www.ksh.hu/docs/ hun/xftp/idoszaki/oktat/oktatas1819.pdf [01.12.2019].

Ostrach Z., „Postrzeganie kształcenia integracyjnego przez rodziców uczniów pełnosprawnych", [in:] Uczeń z niepetnosprawnościa w szkole ogólnodostępnej, Z. Gajdzica (Ed.), Oficyna Wydawnicza “Humanitas", Sosnowiec, 2011, pp. 132-141.

Pachowicz M., "Kształcenie integracyjne - moda czy krok milowy edukacji w Polsce", [in:] Uczeń z niepetnosprawnościa w szkole ogólnodostępnej, Z. Gajdzica (Ed.), Oficyna Wydawnicza "Humanitas", Sosnowiec, 2011, pp. 124-131.

Palak Z., "Tendencje w edukacji dzieci z niepełnosprawnością - szanse i zagrożenia", Lubelski Rocznik Pedagogiczny, no. 2, Vol. XXXVI, 2017, pp. 13-31. DOI: 10.17951/lrp. 2017.36.2.13.

Papp G., "Az integráció, inklúzió fogalmak tartalmi elemzése gyógypedagógiai megközelítésben nemzetközi és magyar színtéren", Gyógypedagógiai Szemle, no. 4, 2012, pp. 295-304.

Parys K., "Zjawisko pozoru w systemie kształcenia uczniów niepełnosprawnych próba identyfikacji i propozycje rozwiązań", Interdyscyplinarne Konteksty Pedagogiki Specjalnej, no. 4, 2014, pp. 29-55.

Ramberg J., Lénárt A., Watkins A. (Eds.), European Agency statistics on inclusive education: 2014 dataset cross-country report, Odense, Denmark, 2014.

Réthy E., Befogadás, méltányosság, az inkluzív pedagógia rendszere. Comenius Oktató és Kiadó Kft., Pécs, 2013.

Réthy E., "Inkluzív pedagógia", [in:] Megközelítések, I. Nahalka, J. Torgyik (Eds.), Eötvös Könyvkiadó, Budapest, 2004, pp. 231-245.

Satoła M., "Edukacja specjalna w państwach Unii Europejskiej", [in:] Postawy wobec niepetnosprawności, L. Frąckiewicz (Ed.), Wydawnictwo Uczelniane Akademii Ekonomicznej im. K. Adamieckiego w Katowicach, Katowice, 2002, pp. 31-52.

Szumski G., Integracyjne ksztatcenie niepetnosprawnych. Sens i granice zmiany edukacyjnej, Wydawnictwo Naukowe PWN, Warsaw, 2006.

Wasielewski K., "Ewolucja systemów oświatowych i postaw młodzieży wobec edukacji w krajach Europy Środkowo-Wschodniej", Kultura $i$ Edukacja, no. 3(117), 2017, pp. 145-163. 
Wdówik P., "Podręczniki i pomoce dydaktyczne dla uczniów z niepełnosprawnościami", Biuletyn Rzecznika Praw Obywatelskich. Źródła, no. 7, 2012, pp. 81-87.

Varga, A., Az inklúzió szemlélete és gyakorlata. Pécsi Tudományegyetem Bölcsészettudományi Kar Neveléstudományi Intézet Romológia és Nevelésszociológia Tanszék Wlislocki Henrik Szakkollégium Pécs, 2015.

Vašek Š., Stankowski A., Zarys pedagogiki specjalnej, Wydawnictwo Uniwersytetu Śląskiego, Katowice, 2006.

Zamkowska A., „Przygotowanie szkoły ogólnodostępnej do kształcenia uczniów upośledzonych umysłowo w stopniu lekkim", [in:] Aktualne problemy edukacji $i$ rehabilitacji osób niepetnosprawnych w biegu życia, Z. Palak, A. Bujnowska, A. Pawlak (Eds.), Wydawnictwo Uniwersytetu Marii Curie-Skłodowskiej, Lublin, 2010, pp. 258-267.

Zaorska M., "Niepełnosprawności sprzężone $\mathrm{w}$ obliczu aktualnych przemian w systemowych rozwiązaniach edukacyjnych", Niepetnosprawność. Dyskursy Pedagogiki Specjalnej, no. 14, 2014, pp. 100-112. 